\title{
Rypsin suorakylvön isoin haaste on hyvä taimettuminen
}

\author{
Hannu Känkänen ${ }^{1)}$ ja Yrjö Salo ${ }^{2)}$ \\ ${ }^{1)}$ Maa- ja elintarviketalouden tutkimuskeskus, Kasvintuotannon tutkimus, 31600 Jokioinen, \\ hannu.kankanen@mtt.ji \\ ${ }^{2)}$ Maa-ja elintarviketalouden tutkimuskeskus, Kasvintuotannon tutkimus, 21500 Piikkiö, \\ yrjo.salo@mtt.fi
}

\section{Tiivistelmä}

Rypsin suorakylvön suurin haaste on riittävän taimitiheyden saavuttaminen. Taimettumisen jälkeen kasvun edellytykset ovat yleensä hyvät. Suorakylvetyn rypsin hyvä menestyminen kokeissa herättää toiveita, sillä suorakylvön viljelykiertoon rypsistä olisi paljon apua. Toisaalta rypsin reagointi erilaisiin kasvuoloihin vaikeuttaa eri ajankohtina kylvettyjen koejäsenten vertailua.

Tasaisesti matala, $2-3 \mathrm{~cm}$ syvyinen kylvö on muokkaamattomassa maassa haasteellista. Maan pinnassa on epätasaisuuksia, eikä pelto ole koskaan joka paikasta yhtä kuivaa. Pintakosteuden vaihdellessa voi etenkin savimaassa osa siemenistä jäädä pintaan tai matalaan avoimeen vakoon, samoin voi vaikuttaa maalajin tai maan tiiviyden vaihtelu. Myös runsaat esikasvin tähteet vaikeuttavat matalaa suorakylvöä. Huolellisesti kylvettäessä siemen kuitenkin menee pääosin sinne minne pitäkin.

Lannoite lähellä siementä estää itämistä. Lannoittamaton suorakylvetty rypsi taimettui Mietoisissa yhtä hyvin kuin muokattuun savimaahan kylvetty rypsi, sen sijaan lannoitteen kanssa suorakylvetyn siemenen taimettuminen jäi noin puoleen. Kun suorakylvössä otettiin käyttöön kaksinkertainen siemenmäärä, päästiin lähes tavanomaiseen taimitiheyteen. Kylvötiheyskokeen tulosten mukaan siemenmäärän kaksinkertaistaminen suorakylvössä oli myös taloudellisesti kannattavaa.

Jokioisissa kynnettyyn savimaahan tehtyä tavanomaista kylvöä verrattiin aikaisemmin, samaan aikaan ja myöhemmin tehtyyn suorakylvöön. Aikainen suorakylvö tehtiin lähes heti, kun se oli teknisesti mahdollista. Myöhäisin kylvö pyrittiin tekemään, kun maa mureni noin neljän sentin syvyyteen. Kevään säät vaikuttivat ratkaisevasti siihen, miten pitkäksi eri kylvöjen väli kasvoi.

Taimettuminen väheni suorakylvön siirtyessä myöhäisemmäksi, mutta kylvöjen jälkeisellä säällä oli suuri merkitys. Jos kylvön jälkeen satoi riittävästi, oli taimettuminen hyvää eikä lannoitteestakaan ollut yhtä suurta haittaa kuin kuivemmalla säällä. Taimettuneiden suorakylvettyjen rypsiyksilöiden kasvu oli normaalioloissa yhtä hyvää kuin tavanomaisesti kylvettyjen. Kylvöajan suuri merkitys tulevalle kasvulle ja säiden ajoittumiselle vaikeutti satojen vertailua kylvömenetelmien välillä. Suorakylvön sato oli samanakin vuonna selvästi isompi tai pienempi kuin jyrsinkylvön sato, kylvöajasta riippuen. Kun kylvöt tehtiin samaan aikaan, oli suorakylvetyn rypsin siemensato yleensä yhtä suuri tai parisataa kiloa hehtaarilta pienempi kuin muokattuun maahan kylvetyn rypsin sato.

Säiltään varsin erilaisten kesien perusteella suorakylvöllä on edellytykset kilpailukykyiseen rypsisatoon, jos taimettuminen saadaan riittävän hyväksi. Kokeissa tähän päästiin tarkan kylvön, hyvien taimettumisolojen ja kaksinkertaisen siemenmäärän avulla. Laatunsa puolesta suorakylvetyn rypsin sato pärjäsi yleensä hyvin tavanomaiselle kylvölle.

Suorakylvöä käyttävän tilan viljelykiertoon rypsi olisi tervetullut lisä. Rypsin viljaa vähäisempi kasvustotähde silppuuntuu pieneksi jo puinnissa ja hajoaa puinnin jälkeen melko nopeasti. Mahdollisesti maa kuivuu keväällä nopeammin, kun haihtumista ja maan lämpenemistä estävää kasvimassaa on vähemmän. Esikasvivaikutusta selvittävä tutkimus alkoi kesällä 2005.

Asiasanat: Kevätrypsi, suorakylvö, muokkaus, lannoitus, kylvötiheys 


\section{Johdanto}

Suorakylvö eli kylväminen suoraan esikasvin sänkeen ilman erillistä muokkausta on yleistynyt voimakkaasti Suomessa viime vuosina. Ensimmäisiä suomalaisia suorakylvötutkimuksia tehtiin 1970luvun jälkipuoliskolla öljyn hintakriisin seurauksena. 1980-luvun lopulta lähtien on tehty yksittäisiä syysviljan suorakylvökokeita, mutta maatalouden taloudellinen tilanne ei aluksi suosinut menetelmään siirtymistä. Kun menetelmän edellytykset taloudelliselta kannalta alkoivat parantua ja viljelijöiden kiinnostus suorakylvöä kohtaan voimakkaasti kasvaa, pystyttiin tutkimuksenkin resursseja lisäämään. MTT:n kevätviljan suorakylvötutkimus voimistui vuonna 2000, ja vuodesta 2002 lähtien Maa- ja metsätalousministeriö on rahoittanut kevätviljan suorakylvöhankkeita. Kevätviljatutkimus loi tekniset mahdollisuudet myös rypsin suorakylvön tutkimiselle, kun rypsin viljelyvarmuuden parantamiseen tähtäävän tutkimushankkeen $(2002$ - 2005) yhdeksi tutkimusaiheeksi valittiin suorakylvö.

Kuten tutkimus, myös käytännön suorakylvö on keskittynyt lähinnä viljoihin. Rypsi kuuluu kuitenkin useimpien viljatilojen kasvivalikoimaan, ja rypsin merkitys viljelykierron osana lienee suorakylvöä käytettäessä vieläkin tärkeämpi kuin kylvettäessä muokattuun maahan. Kun Jokioisissa vuonna 2005 aloitettiin suorakylvön viljelykierron kehittämiseen pyrkivä hanke, oli rypsi itseoikeutetusti mukana tutkittavien kasvien joukossa, vaikka rahoituksen niukkuuden vuoksi jouduttiin monia kasveja jättämään tutkimuksesta pois.

Rypsin viljelyvarmuuden parantaminen -hankkeen yksi päätavoitteista oli rypsikasvuston onnistunut perustaminen hyvän ja tasaisen taimettumisen avulla. Vaikka rypsin suorakylvössä savimaahan arvioitiin jo etukäteen kohdattavan vaikeuksia, katsottiin suorakylvömenetelmän sisältävän hankkeen tavoitteiden mukaisia etuja. Tärkein näistä ennakko-odotuksista oli se, että muokkaamaton maa ei kuivu rypsin kylvön kannalta liian kuivaksi niin helposti kuin kynnetty ja muokattu maa. Hankkeen tutkimukset tehtiin hienojakoisilla eli savimailla, joilla onnistunut kylvö ja siementä peittävän murukerroksen aikaansaaminen on haasteellisempaa mutta maassa olevan kasvimateriaalin ja rikkakasvien aiheuttamat ongelmat vähäisempiä kuin kevyemmillä maalajeilla.

\section{Aineisto ja menetelmät}

Artikkelin aineisto on pääosin peräisin Rypsin viljelyvarmuuden parantaminen -hankkeen suorakylvökokeista. Koska rypsin suorakylvö on tutkimusaiheena uusi ja menetelmä vielä osittain kehitysvaiheessa, esitetään tässä myös ensimmäisen vuoden tuloksia suorakylvön viljelykierron monipuolisuuden lisäämiseen tähtäävästä hankkeesta niiltä osin, kuin ne rypsin osalta lisäävät tietämystä. Näiden kahden tutkimuksen välillä on myös se ero, että edellisen kokeet tehtiin pelloilla, jotka siihen asti oli viljely kyntäen, mutta jälkimmäistä edelsi kahden kesän suorakylvö. Molempia voidaan kuitenkin kutsua siirtymävaiheen kokeiksi, sillä suorakylvettävän maan pintarakenteen muuttumiseen muokkaamattomalle maalle ominaiseksi on arvioitu kuluvan aikaa noin viisi vuotta.

Rypsin viljelyvarmuuden parantaminen -hankkeen (2002 - 2005) suorakylvötutkimuksia tehtiin Jokioisilla ja Mietoisissa. Molemmilla koepaikoilla suorakylvö tehtiin Vieskan Metallin kolmimetrisellä suorakylvökoneella, jolla siemen ja lannoite kylvetään samaan kylvövakoon. Kokeissa suorakylvöjä verrattiin tavanomaiseen muokatun maan kylvöön, joka tehtiin laahavantaisella Tume kylvölannoittimella. Molemmilla koepaikoilla tavanomainen kylvö tehtiin aina syksyllä kynnettyyn, keväällä ennen kylvöä tasausäestettyyn maahan. Jokioisilla käytettiin jyrsinkylvöyhdistelmää, Mietoisissa maa muokattiin joustopiikkiäkeellä ennen kylvölannoitusta.

Jokioisten kylvöaikakokeissa (2002 - 2004) ensimmäinen suorakylvö tehtiin pian sen jälkeen, kun suorakylvö oli maan kosteuden kannalta teknisesti mahdollista. Tavanomainen kylvö tehtiin perustamisen kannalta mahdollisimman edullisena ajankohtana, ja toinen suorakylvö tehtiin samaan aikaan tavanomaisen kylvön kanssa. Myöhäisin kylvö pyrittiin tekemään, kun maa mureni sopivasti pinnastaan. Kevään säät vaikuttivat ratkaisevasti siihen, miten pitkäksi eri kylvöjen väli kasvoi. Ensimmäinen suorakylvö, tavanomainen kylvö, toinen suorakylvö ja kolmas suorakylvö tehtiin eri vuosina seuraavina päivinä: 2002: 24.4., 3.5., 3.5. ja 23.5., 2003: 9.5., 28.5., 29.5. ja 4.6., 2004: 29.4., 3.5., 3.5. ja 6.6.

Ensimmäisenä koevuonna molemmilla kylvötavoilla käytettiin samaa siemenmäärää (300 itävää siementä neliömetrille), mutta kahtena seuraavana vuonna suorakylvön siemenmäärä 
kaksinkertaistettiin hankkeessa saatujen taimettumistulosten myötä. Vuonna 2002 siemenen itävyys oli $95 \%$ ja 1000 siemenen paino 2,61 g, vuonna $200391 \%$ ja 2,72 g, ja vuonna $200489 \%$ ja 3,14 g. Siemen oli jokaisena vuonna Valo-lajiketta, joka oli peitattu Cruiserilla. Kylvötavasta ja -ajasta riippumatta typpeä annettiin $110 \mathrm{~kg} / \mathrm{ha}$. NPK-lannos valittiin koealueen viljavuuden mukaan vähintään rypsin tarvetta vastaavasti. Fosforilannoitus oli ensimmäisenä vuonna $28 \mathrm{~kg} / \mathrm{ha}$ ja kahtena muuna vuonna $17 \mathrm{~kg} / \mathrm{ha}$, kaliumin vastaavasti 22 ja $44 \mathrm{~kg} / \mathrm{ha}$. Ruutukoko oli 6 x $20 \mathrm{~m}$, ja koemalli oli täydellisesti satunnaistettujen lohkojen koe neljällä toistolla.

Mietoisissa tutkittiin erilaisia suorakylvön siemenmääriä. Normaali siemenmäärä $\left(350 \mathrm{kpl} / \mathrm{m}^{2}\right)$ vaihteli vuosittain välillä $8-11 \mathrm{~kg} / \mathrm{ha}$. Kahdessa muussa koejäsenessä siemenmäärää lisättiin $50 \mathrm{ja}$ $100 \%$ normaaliin verrattuna. Lannoitus oli joka vuosi $600 \mathrm{~kg} / \mathrm{ha}$ Y3-lannosta, eli $120 \mathrm{~kg} / \mathrm{ha}$ typpeä, 18 fosforia ja 48 kaliumia. Samalla testattiin lannoitteen vaikutusta taimettumiseen tekemällä suorakylvö myös ilman lannoitetta normaalilla siemenmäärällä. Suorakylvöjä verrattiin tavanomaisesti kynnettyyn ja muokattuun kylvöön. Ruutukoko oli 6 × $20 \mathrm{~m}$, ja koemalli oli täydellisesti satunnaistettujen lohkojen koe neljällä toistolla. Suorakylvöpäivät vuosina 2002, 2003 ja 2004 olivat 9.5., 9.6. ja 6.5., tavanomaisen kylvön päivät vastaavasti 10.5., 11.6. ja 11.5.

Vuonna 2005 aloitettiin Jokioisissa yksivuotisten kasvien suorakylvöä ja esikasviominaisuuksia selvittävä kenttäkoe. Yksi kylvetyistä kasveista oli kevätrypsi, lajikkeena Hohto. Tavanomainen kylvö tehtiin 3.5. ja suorakylvö viikkoa myöhemmin, kun myös sänkimaa oli kuivunut kylvökelpoiseksi. Ruutujen koko on 6 x 20 m. Koe toteutetaan osaruutukokeena (split-plot) neljällä toistolla.

\section{Tulokset}

Kenttäkokeelle tyypillisesti sääolot vaikuttivat voimakkaasti kasvien kasvuun. Kun on kyse eri kylvöaikojen ja kylvöajoiltaan poikkeavien kylvötapojen vertailusta, on säätekijöillä usein ratkaiseva merkitys tulosten eroihin. Jokioisten kolmen vuoden aikana tehdyissä kylvöaikakokeissa jouduttiinkin monen muuttujan osalta poimimaan vertailukelpoiset tulokset. Vuoden 2004 ankara kahden yön halla kolmen ensimmäisen kylvön taimivaiheessa ja viimeisen kylvön taimivaiheeseen osuneet runsaat sateet muuttivat kasvun edellytyksiä niin voimakkaasti, että tuloksia pitää tarkastella hyvin kriittisesti. Toisaalta ensimmäisenä koevuonna käytettiin suorakylvössä vielä liian alhaista siemenmäärää, mikä asetti menetelmän jo lähtökohtaisesti tavanomaista kylvöä heikompaan asemaan.

\section{Kasvun alku}

Suorakylvetyn rypsin taimettuminen jäi noin puoleen tavanomaisesta Jokioisten kylvöaikakokeissa (kuva 1). Heikon taimettumisen pääsyy oli ilmeisesti samaan kylvövakoon kylvetty lannoite, sillä Mietoisissa suorakylvetty rypsi taimettui selvästi paremmin ilman lannoitetta kuin lannoitteen kanssa. Jokioisissa tehtiin myös pieni astiatesti, jossa lähellä olevat lannoiterakeet estivät siemenen itämisen.

Paitsi lannoite, haittasi kylvöjäljen vaihtelevuus usein taimettumista. Savimaa ei ollut eri kohdistaan kosteudeltaan, kovuudeltaan ja pinnanmuodoiltaan tasalaatuista, joten matalaan $(2-3 \mathrm{~cm})$ kylvöön pyrittäessä vako jäi paikoin liian matalaksi ja avoimeksi. Suorakylvön siirtyminen myöhäisemmäksi vähensi taimien määrää, vaikka maan kylvettävyys teoriassa parani kuivumisen myötä. Toisaalta aikaisten kylvöjen jälkeen tuli sateita, mikä paransi taimettumista. Vuonna 2004 viimeinen kylvö taimettui erittäin hyvin, koska maa oli edeltävien sateiden vuoksi kosteaa ja kylvön jälkeenkin satoi. Vertailua aikaisempiin kylvöihin ei kuitenkaan voitu tehdä, koska suuri osa niiden taimista tuhoutui halloissa. Myös esikasvin puinnissa syntyneet olkikerrokset huononsivat kylvön onnistumista, ja taimien määrä oli olkisissa kohdissa vähäolkisia kohtia pienempi.

Lannoittamaton suorakylvetty rypsi taimettui Mietoisissa yhtä hyvin kuin kynnettyyn ja muokattuun maahan kylvetty lannoitettu rypsi (taulukko 1). Sen sijaan lannoitetun suorakylvetyn rypsin taimitiheys jäi noin puoleen edellä mainituista vuosina 2002 ja 2004. Vuonna 2003 lannoitteesta oli vain vähän haittaa, ja suorakylvettyjen rypsien taimitiheydet olivat selvästi tavanomaisesti kylvettyä suuremmat. Sääoloilla lienee osuutensa vuosien eroihin. Alkukesät $2002 \mathrm{ja}$ 2004 olivat hyvin kuivia. Vuonna 2003 satoi toukokuussa erittäin runsaasti, ja myös pian sen jälkeen kun kesäkuussa päästiin kylvämään, satoi melko runsaasti. 


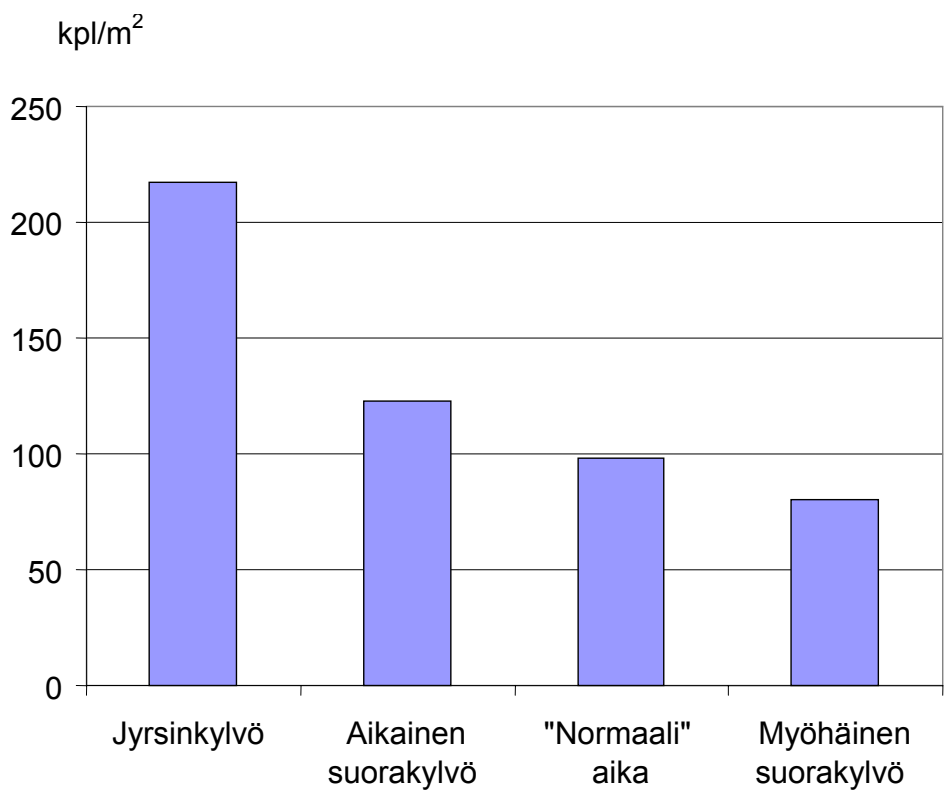

Kuva 1: Rypsin taimien määrä 300 kylvettyä itävää siementä kohti Jokioisten suorakylvökokeessa keskimäärin vuosina 2002 - 2003. Vuoden 2003 suorakylvössä käytettiin jo kaksinkertaista siemenmäärää, mikä on tässä kuvassa huomioitu jakamalla taimimäärä kahdella. Vuoden 2004 taimitiheyksiä ei tässä ole, koska halla harvensi pahasti kolmen ensimmäisen kylvön taimia, ennen kuin oikea taimettumisen tiheys ehdittiin niistä määrittää. Ns. normaaliajan suorakylvö on tehty samaan aikaan kynnetyn maan jyrsinkylvön kanssa.

\begin{tabular}{|c|c|c|c|c|c|c|}
\hline \multirow[b]{2}{*}{$\begin{array}{l}\text { Kylvö- } \\
\text { menetelmä }\end{array}$} & \multirow[b]{2}{*}{$\begin{array}{l}\text { Siemen- } \\
\text { määrää }\end{array}$} & \multirow[b]{2}{*}{$\begin{array}{l}\text { Siementä } \\
\mathrm{kpl} / \mathrm{m}^{2}\end{array}$} & \multicolumn{3}{|c|}{ Taimitiheys, kpl/m $\mathbf{m}^{2}$} & \multirow[b]{2}{*}{$\begin{array}{l}\text { Keski- } \\
\text { määrin }\end{array}$} \\
\hline & & & $\begin{array}{l}\text { Vuosi } \\
2002 \\
\end{array}$ & 2003 & 2004 & \\
\hline Tavanomainen & normaali & 350 & 227 & 149 & 257 & 211 \\
\hline Suorakylvö & normaali & 350 & 135 & 228 & 108 & 157 \\
\hline Suorakylvö & $+50 \%$ & 525 & 144 & 240 & 171 & 185 \\
\hline Suorakylvö & $+100 \%$ & 700 & 216 & 325 & 169 & 237 \\
\hline \multicolumn{7}{|l|}{ Lannoittamaton } \\
\hline suorakylvö & normaali & 350 & 277 & 240 & 264 & 260 \\
\hline
\end{tabular}

Taulukko 1: Rypsin taimitiheys Mietoisten suorakylvökokeessa vuosina 2002 - 2004. Tavanomaisesti kynnetyn ja muokatun maan kylvöä normaalilla siemenmäärällä verrattiin suorakylvöön normaalilla, puolitoistakertaisella ja kaksinkertaisella siemenmäärällä. Lisäksi tutkittiin normaalia siemenmäärää käyttäen, miten lannoitteen pois jättäminen vaikuttaa suorakylvetyn rypsin taimettumiseen.

\section{Biomassan kertyminen}

Rypsiyksilöiden biomassan kertymistä pyrittiin Jokioisten kylvöaikakokeissa seuraamaan määräalalta otettujen kasvinäytteiden avulla. Vuonna 2002 taimitiheyksissä oli suuret erot ja edustavien näytteiden saaminen harvoista kasvustoista kyseenalaista. Vuonna 2004 hallat ja sateet vaikuttivat ratkaisevasti eri kylvöjen kasvuun. Kolmen vuoden kokeista voidaankin suhteellisen luotettavasti tarkastella vain yhden vuoden tuloksia, kun kyse on kylvömenetelmän ja suorakylvön ajankohdan vaikutuksesta rypsiyksilöiden kasvun rehevyyteen. Vuonna 2003 suorakylvössä käytettiin jo kaksinkertaista siemenmäärää, ja taimitiheydet olivat lähellä toisiaan. Nuppuvaiheessa kylvömenetelmien välillä ei ollut eroa, mutta rypsille tyypillisesti aikaisen kylvön taimet olivat muita pienempiä (kuva 2). Kukintavaiheessa kasviyksilöt olivat suorakylvettynä suurempia kuin tavanomaisesti kylvettynä. Alustavien tulosten mukaan kylvömenetelmä ei vaikuta rypsin kehitysrytmiin suoraan, mutta välillisesti vaikutus voi olla suurikin kylvöajan muutosten kautta. 


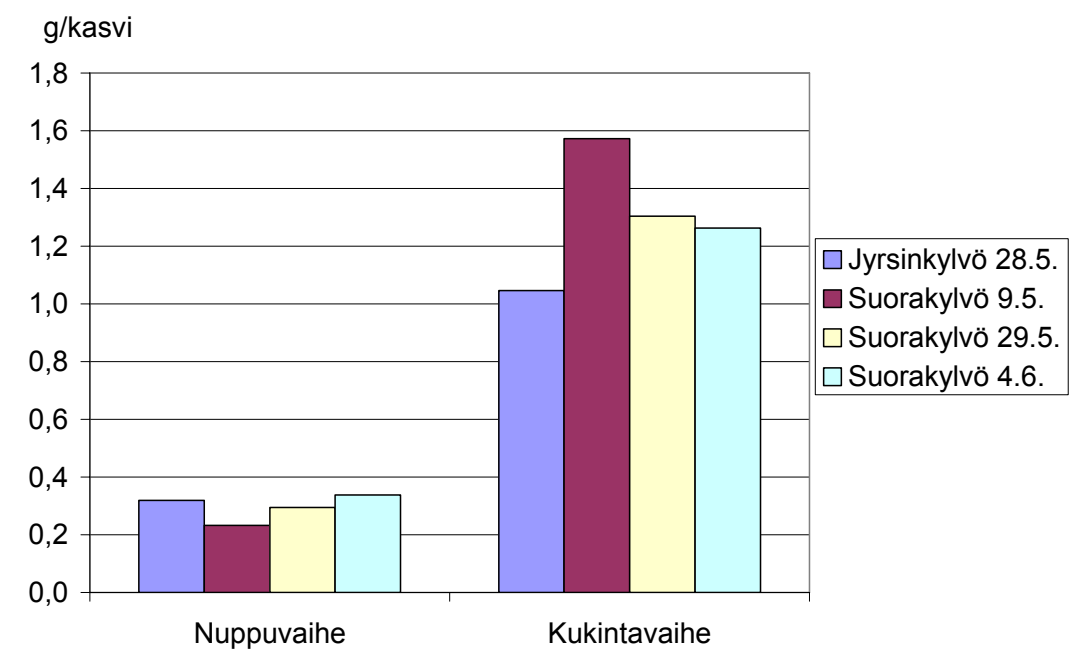

Kuva 2: Rypsiyksilöiden kuivapaino nuppu- ja täyskukintavaiheessa vuonna 2003 Jokioisissa. Jyrsinkylvö on tavanomainen kylvö kynnettyyn ja muokattuun maahan parhaaseen mahdolliseen aikaan. Suorakylvöt on tehty muokkaamattomaan edellisvuoden kevätviljan sänkeen. Selitteen päivämäärät ovat kylvöpäiviä.

\section{Siemensadon määrä ja laatu}

Aiemmin mainittu säätekijöiden voimakas vaikutus kasvuun Jokioisten kylvöaikakokeissa heijastui luonnollisesti myös siemensadon määrään. Kesän 2002 sato oli koko kokeessa heikko, mutta suorakylvö pääsi lähelle tavanomaisen kylvön satoa (kuva 3). Samaan aikaan jyrsinkylvön kanssa tehty suorakylvö tuotti vain $80 \mathrm{~kg} / \mathrm{ha}$ pienemmän sadon, vaikka taimitiheys oli noin puolet jyrsinkylvön tiheydestä ja noin neljäsosan tavoitellusta tiheydestä. Vuoden 2004 satoon antoi leimansa aikaisten kylvöjen taimivaiheen halla ja viimeisen kylvön kasvuston tukehduttanut sade. Parhaiten vertailukelpoisia ovat samaan aikaan tehdyt kylvöt, eli jyrsinkylvö ja toinen suorakylvö. Näiden kahden välinen satoero oli $200 \mathrm{~kg} /$ ha tavanomaisen kylvön eduksi. Vuonna 2003 sääolot olivat eri koejäsenille tasapuolisimmat, tosin aikainen suorakylvö hyötyi viileämmästä säästä kukinta-aikaan, minkä ansiosta sen kukinta kesti viikon pidempään kuin muiden kylvöjen. Ensimmäisen suorakylvön siemensato oli lähes $200 \mathrm{~kg} / \mathrm{ha}$ suurempi kuin tavanomaisen kylvön ja sen kanssa samaan aikaan tehdyn toisen suorakylvön. Kolmannen suorakylvön sato jäi pienimmäksi myös v. 2003.

Mietoisten siemenmääräkokeissa suorakylvö tavanomaisen kylvön siemenmäärällä tuotti keskimäärin $100 \mathrm{~kg} / \mathrm{ha}$ pienemmän siemensadon kuin tavanomainen kylvö (taulukko 2). Siemensato nousi tavanomaisen kylvötavan tasolle, kun kylvötiheyttä lisättiin puolitoistakertaiseksi, ja noin 200 $\mathrm{kg}$ /ha korkeammaksi kuin tavanomaisessa kylvössä, kun siemenmäärä kaksinkertaistettiin. Tulosten pohjalta laskettiin myös suorakylvön siemenmäärän lisäämisen kannattavuutta. Laskelmassa käytetty kevätrypsin siemenen hinta oli $2,942 € / \mathrm{kg}$ ja sadon myyntiarvo $176,65 € / \mathrm{tn}$, josta vähennettiin kuivaus-, rahti- ja välityskustannukset. Laskelman mukaan siemenmäärän lisääminen puolitoistakertaiseksi lisäsi hehtaarilta saatavaa katetta noin 9 euroa ja kaksinkertaistaminen noin 24 euroa.

Rypsisadon laatu riippuu paljolti siitä, miten hyvä kasvusto saadaan perustetuksi ja millaiset sääolot kasvuston kehittymisen aikana vallitsevat. Näin myös kylvöaikakokeissa suorakylvön ajankohta vaikutti enemmän laatuun kuin kylvömenetelmä. Kylvötiheyskokeessa siemensadosta määritettiin vain 1000 siemenen paino ja puhtaus. Kylvötiheyden lisääntyminen pienensi hieman siemenkokoa, mikä on seurausta pienemmästä kasvutilasta. Vuonna 2002, jolloin sato oli normaalia roskaisempaa, paransi kylvötiheyden lisääntyminen sadon puhtautta. Tavanomaisella siemenmäärällä sadon puhtaus oli 91,9\%, kaksinkertaisella siemenmäärällä 95,9 \%. Muina vuosina ei roskia ollut käytännöllisesti katsoen lainkaan millään siemenmäärällä eikä kummallakaan kylvötavalla. Glyfosaattiruiskutus tarvittaessa ennen kylvöä ja tehokas torjunta viljelykierron aiemmissa vaiheissa pitivät rikkakasvit kurissa. Lisää aineistoa kuitenkin tarvitaan sen tutkimiseen, vaikuttaako suorakylvö rypsin sadon laatuun. 


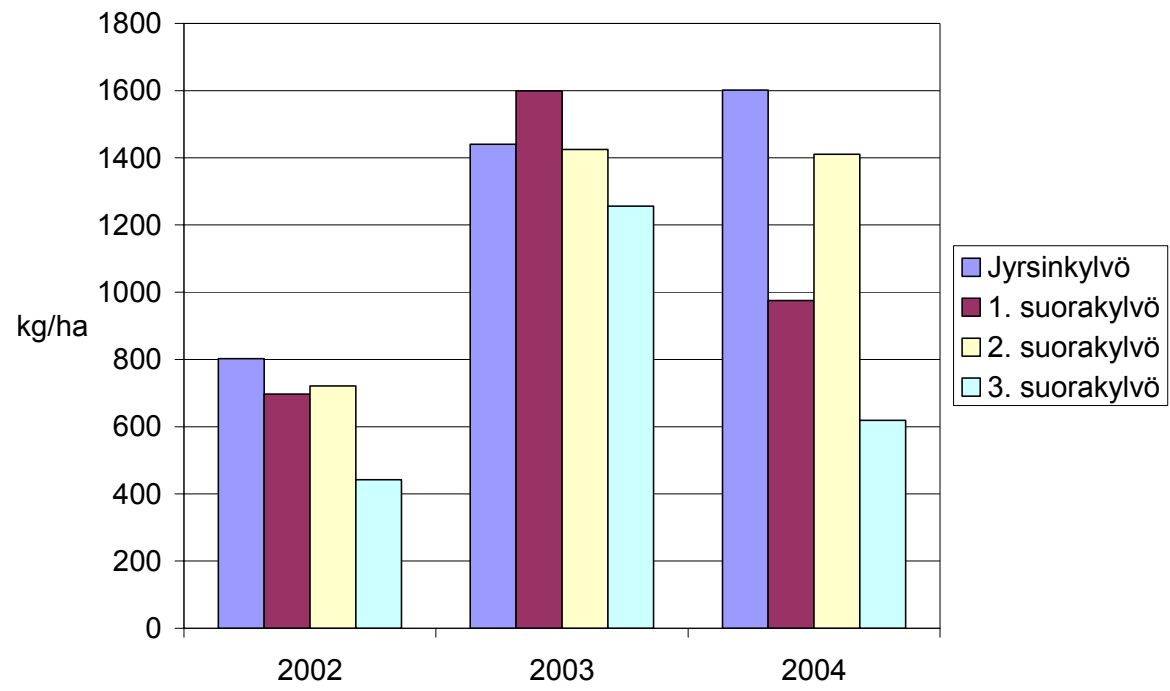

Kuva 3: Rypsin siemensato Jokioisten kylvöaikakokeessa vuosina 2002 - 2004. Jyrsinkylvö on tavanomainen kylvö kynnettyyn ja muokattuun maahan parhaaseen mahdolliseen aikaan, 1. suorakylvö tehtiin mahdollisimman aikaisin, 2. suorakylvö tehtiin samaan aikaan jyrsinkylvön kanssa ja 3. suorakylvö pyrittiin tekemään, kun maa murentui viljan kylvösyvyyteen asti. Toteutuneet kylvöpäivät on kerrottu tekstissä. Säät vaikuttivat ratkaisevasti eri kylvöjen erilaiseen kasvuun vuonna 2004 (kerrottu tarkemmin tekstissä). Vuonna 2002 suorakylvössä käytettiin samaa siemenmäärää kuin jyrsinkylvössä, seuraavina vuosina kaksinkertaista siemenmäärää.

\begin{tabular}{|c|c|c|c|c|c|c|}
\hline \multirow[b]{2}{*}{$\begin{array}{l}\text { Kylvö- } \\
\text { menetelmä }\end{array}$} & \multirow[b]{2}{*}{$\begin{array}{l}\text { Siemen- } \\
\text { määrä }\end{array}$} & \multirow[b]{2}{*}{$\begin{array}{l}\text { Siementä } \\
\mathrm{kpl} / \mathrm{m}^{2}\end{array}$} & \multicolumn{3}{|c|}{ Siemensato, kg/ha } & \multirow[b]{2}{*}{$\begin{array}{l}\text { Keski- } \\
\text { määrin }\end{array}$} \\
\hline & & & $\begin{array}{l}\text { Vuosi } \\
2002\end{array}$ & 2003 & 2004 & \\
\hline Tavanomainen & normaali & 350 & 1690 & 960 & 1520 & 1390 \\
\hline Suorakylvö & normaali & 350 & 1240 & 1010 & 1620 & 1290 \\
\hline Suorakylvö & $+50 \%$ & 525 & 1430 & 1090 & 1750 & 1420 \\
\hline Suorakylvö & $+100 \%$ & 700 & 1660 & 1140 & 1930 & 1580 \\
\hline
\end{tabular}

Taulukko 2: Rypsin siemensato Mietoisten kylvötiheyskokeessa vuosina 2002 - 2004. Tavanomainen kylvömenetelmä on syksyllä kynnettyyn sekä keväällä tasattuun ja muokattuun maahan tehty kylvö. Tavanomainen kylvö pyrittiin tekemään mahdollisimman edulliseen aikaan, suorakylvöt tehtiin hieman tavanomaista kylvöä aiemmin. Kylvöpäivämäärät on kerrottu tekstissä.

\section{Kokemukset kesältä 2005}

Uuden suorakylvötutkimuksen ensimmäisenä kesänä rypsi taimettui viidestä suorakylvetystä kasvista parhaiten, kun suorakylvöä verrattiin tavanomaisen kylvöön. Tähän tosin vaikutti oleellisesti rypsin kaksinkertainen siemenmäärä suorakylvössä. Alkukesä oli otollinen suorakylvölle, sillä pienet, usein toistuvat sateet sopivat paremmin tiiviille suorakylvöalustalle kuin kuohkeaksi muokatulle maalle. Taimia suorakylvössä oli viidenneksen tiheämmässä kuin tavanomaisessa kylvössä, ja kun kasviyksilöiden kasvu muutenkin oli nuppuasteelle asti ainakin samanveroista, oli suorakylvetty rypsikasvusto alkukesällä todella rehevä. Loppukesällä suorakylvetyt kasviyksilöt kasvoivat hieman heikommin kuin tavanomaisesti kylvetyt, ja siemensato oli lopulta noin $10 \%$ tavanomaista pienempi.

\section{Tulosten tarkastelu}

Rypsin kasvun herkkä reagointi erilaisiin kasvuoloihin hankaloittaa suorakylvön oikean ajankohdan määrittämistä koetulosten avulla. Muokkaamattoman maan hitaamman kuivumisen vuoksi suorakylvön paras ajankohta on yleisesti todettu tavanomaista kylvöä myöhäisemmäksi (Alakukku 2004) mikä merkitsee em. ongelman ulottumista myös menetelmien vertailuun. Toisaalta kylvöaikakokeissa rypsi taimettui yleensä heikoimmin viimeisessä kylvössä, joka pyrittiin tekemään maan murentuessa viljan kylvösyvyyteen asti. Savimaan pintakerroksen liiallinen kuivuminen voikin olla riski myös suorakylvössä. Onkin mahdollista, että rypsin matalan kylvön ansiosta suorakylvön paras aika on varsin lähellä rypsin tavallista kylvöaikaa, etenkin kun kylvöä kylmään maahan 
suositellaan välttämään (Franssila ym. 2001). Luotettavinta lieneekin verrata tavanomaista kylvöä samaan aikaan tai vain vähän myöhemmin tehtyyn suorakylvöön.

Rypsin suorakylvöä on tutkittu vasta varsin vähän, etenkin kun ottaa huomioon, että kaikkien tutkittavien muuttujien osalta ei jokaisena kesänä ole saatu vertailukelpoisia tuloksia poikkeavien kasvuolojen vuoksi. On kuitenkin ilmeistä, että suorakylvetyllä rypsillä on hyvät edellytykset kasvaa hyvin ja tuottaa kunnollinen siemensato, jos taimettuminen saadaan onnistumaan eikä vettä sada ylimäärin kasvun aikana. Niin biomassan määrän kuin kehitysrytminkin seuranta on osoittanut, että hyvän alun saanut suorakylvetty rypsi kasvaa siinä missä tavanomaisesti kylvettykin, jos kasvuolot ovat tasavertaiset.

Näyttää siltä, että rypsin suorakylvön suurin haaste on hyvän taimitiheyden saavuttaminen. Lannoite samassa vaossa estää siemenen itämistä ja taimettumista. Lannoitteen kanssa samaan kylvövakoon savimaahan suorakylvetty rypsi näyttäisikin hyvin taimettuakseen edellyttävän tavanomaista kosteampaa maata, ja kylvön jälkeen saatavat sateet auttavat oleellisesti taimettumista. Vaihtelu vuosien välillä on suurta, mutta keskimäärin suorakylvö yhdessä lannoitteen kanssa vaatii kaksinkertaista siemenmäärää saman taimitiheyden saavuttamiseksi. Vaikka siemenmäärän kaksinkertaistaminen voi olla taloudellisesti kannattavaa suorakylvöä käytettäessä, olisi taimettuminen syytä saada tavanomaisen kylvön tasolle, esimerkiksi rypsin suorakylvöön sopivan lannoitteen avulla tai kylvötekniikkaa kehittämällä. Myös esikasvin runsas kasvustotähde vaikeuttaa erityisesti pienten siementen kylvöä, joten olkien hyvään silppuuntumiseen sekä silpun ja ruumenten tasaiseen levittämiseen tulee puinnissa kiinnittää huomiota (Mikkola 2004). Viljelykierto on syytä suunnitella niin, että rypsi ei seuraa kaikkein runsasolkisimpia kasveja.

Rypsi on hyvä viljan esikasvi ja se olisi syytä saada mukaan myös suorakylvön viljelykiertoon (Känkänen ym. 2005). Vaikka rypsin ominaisuuksien tutkiminen nimenomaan suorakylvön viljelykierron kannalta on vasta aloitettu, voidaan sillä jo nyt todeta todennäköisesti olevan useita etuja. Yksi tärkeimmistä lienee viljoja pienempi kasvintähteiden määrä, mikä helpottaa seuraavan kasvin kylvöä. Pelloilla, joilla lierojen määrä ei riitä kasvintähteiden tehokkaaseen multaamiseen (Nuutinen 2004) ja joilla halutaan kokonaan välttää koneellinen olkien maahan muokkaaminen, voi rypsin tai muiden vähän kasvintähteitä tuottavien kasvien viljely olla jopa välttämätöntä.

\section{Kirjallisuus}

Alakukku, L. 2004. Suorakylvön ajoitus ja työsyvyys määräytyy savimaan kosteuden mukaan. Maataloustieteen Päivät 2004 (verkkojulkaisu). Suomen Maataloustieteellisen Seuran julkaisuja no. 19. toim. Anneli Happonen ja Marketta Rinne. 5.1.2004. http://www.agronet.fi/maataloustieteellinenseura/ ISBN 951-9041-47-8.

Franssila, E., Lundström, G., Rytsä E. \& Tulisalo U. 2001. Öljykasvinviljelijän opas. Maa- ja metsätaloustuottajain Keskusliitto MTK ja Elintarviketeollisuusliiton Öljynpuristamoyhdistys.

Mikkola, H. 2004. Suorakylvöalustan valmistaminen. In: Suorakylvöopas (eds. Alakukku, L., Míkkola, H. \& Teräväinen, H.). ProAgria. Maaseutukeskusten liitto Tieto tuottamaan 107: 24-29.

Känkänen, H., Alakukku, L., Kangas, A., Salo, Y. \& Laine, A. 2005. Suorakylvön viljelykierto vaatii erityisharkintaa. Käytännön maamies 54, 6: 42-44.

Nuutinen, V. 2004. Suorakylvömaan ekosysteemi-insinöörit. In: Suorakylvöopas (eds. Alakukku, L., Míkkola, H. \& Teräväinen, H.). ProAgria. Maaseutukeskusten liitto Tieto tuottamaan 107: 16 - 19. 